\title{
Efficacy of the Speaking and Writing ESP Modules for Working Adults: Government Officials
}

Omar Lin, Nalini Arumugam, Aung Soe Lwin, Misyana Susanti, Faizah Mohamad

To Link this Article: http://dx.doi.org/10.6007/IJARBSS/v11-i3/9667

DOI:10.6007/IJARBSS/v11-i3/9667

Received: 11 January 2021, Revised: 13 February 2021, Accepted: 26 February 2021

Published Online: 15 March 2021

In-Text Citation: (Lin et al., 2021)

To Cite this Article: Lin, O., Arumugam, N., Lwin, A. S., Susanti, M., \& Mohamad, F. (2021). Efficacy of the Speaking and Writing ESP Modules for Working Adults: Government Officials. International Journal of Academic Research in Business and Social Sciences, 11(3), 1484-1501.

Copyright: (C) 2021 The Author(s)

Published by Human Resource Management Academic Research Society (www.hrmars.com)

This article is published under the Creative Commons Attribution (CC BY 4.0) license. Anyone may reproduce, distribute, translate and create derivative works of this article (for both commercial and non-commercial purposes), subject to full attribution to the original publication and authors. The full terms of this license may be seen at: $\underline{\text { http://creativecommons.org/licences/by/4.0/legalcode }}$

Vol. 11, No. 3, 2021, Pg. 1484 - 1501

Full Terms \& Conditions of access and use can be found at http://hrmars.com/index.php/pages/detail/publication-ethics 


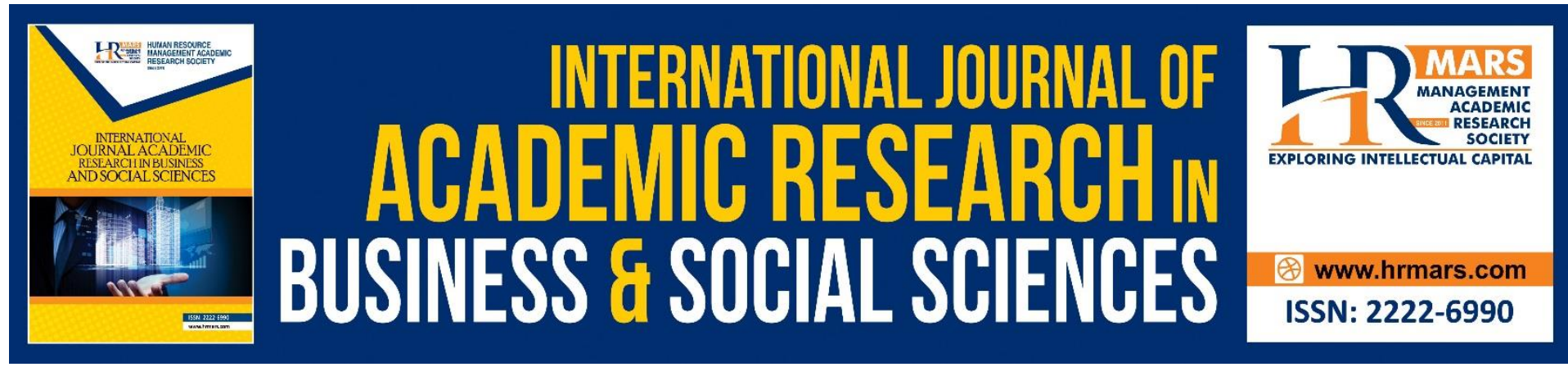

\title{
Efficacy of the Speaking and Writing ESP Modules for Working Adults: Government Officials
}

\author{
Omar Lin, Nalini Arumugam, Aung Soe Lwin, Misyana Susanti, \\ Faizah Mohamad \\ Ministry of Investment and Foreign Economics Relations, Myanmar, Akademi Pengajian \\ Bahasa, Universiti Teknologi MARA, Shah Alam, Akademi Pengajian Bahasa, Universiti \\ Teknologi MARA, Alor Gajah, Myanmar Institute of Education, Myanmar \\ Email: nalini@uitm.edu.my
}

\begin{abstract}
The study investigated the effects of ESP speaking and writing modules on government officials' speaking and writing skills in Myanmar. 25 high ranked and 25 low ranked government officials participated in this quasi-experimental study for a 2-day workshop. A mixed methods case study approach was employed in which both quantitative and qualitative data were collected in the study the respondents were required to sit for pre and post-tests and semi-structured interviews were carried out to elicit information. The results revealed that there were significant differences between the pre and post-test scores in the Speaking and Writing skills for both the high ranked and low ranked government officials. The results also indicated a favourable view of ESP modules as an instructional approach to enhance one's English language skills to execute their duties effectively. This study adds insights into pedagogical approaches used in the workplace and recommendations are suggested for further research.
\end{abstract}

Keywords: ESP, Speaking Skills, Writing Skills, Government Officials, Workplace.

\section{Introduction}

The international communities deserted Myanmar for many decades due to the political instability Stokke, Vakulchuk, \& Overland (2018). However, Myanmar has opened itself to the world for nearly a decade and experienced the flourishing world economy and globalization; and therefore its people's life and education have been changing along with the fast development of the country (The British Academy, 2015). A growing number of foreign companies and businesses varying from telecom, construction, shopping mall, luxury housing, hotel and education have entered invested in the country recently. As a result, international relations, import, export and other businesses that have been growing involves lots of international travel and communication with foreign partners and partner institution. In view of this, the government has been sending senior officers and university faculty members to overseas for seminars, conferences, and training courses (Department of Higher Education, 2012; MOE, 2013). The country is expecting more foreign investments as the new government has been in place working towards a democracy regime with a strengthening of foreign direct 
investment policy (FDI). In line with this development in Myanmar, English Language instruction is made compulsory at all levels of education though it is taught as one of the foreign languages.

Myanmar is becoming increasingly integrated in the global economy and expanding as a key player in the Association of South East Asian Nations (ASEAN). In 2009 the 10 nations comprising the ASEAN, including Myanmar officially recognized English as the sole operational language of the organization (Kirkpatrick, 2014). Now it is speculated that the future generation face a challenge if they are not ready to enhance their proficiency in the English language. As a result, the Myanmar government decided to reform the English language pedagogy and its training to improve national education system (Soe, 2015). Hence the English language is made as a compulsory subject government school.

As Myanmar intends to partake actively in the global economic system by inviting foreign investors and strengthening diplomatic relationships with the outside world, the nature of daily work requires good proficiency of English language especially among the national government officials (Department of Higher Education, 2012b). Such necessity has led to a need to create an effective system where the English communicative skills of the government officials can be improved.

Additionally, it has been found that the demand of oral communication is greater in the Myanmar society as many foreign companies are interested to invest their business and industries in Myanmar. Another reason for the demand for oral communication is the growth of tourism industry. Currently, in Myanmar tourism and other businesses related to tourism are soaring and is becoming the main business for the national economy (Myanmar Institute for Integrated Development, 2018). As a result, in society, people come to realize the need for oral competency in English as there is a need to communicate with the tourists and employers from foreign countries. A diplomatic language is means not merely a means of communication but the key pillar of diplomatic rapport. English language is always used as a medium of communication during meetings and international institutions (Gjata, 2017).

ESP is a method of language education where the content is prescribed and technique is developed based on the students' need for learning (Hutchinson \& Waters, 1987). They further explain that the English language is accepted as the lingua franca not only in communication but also in technology and commerce. Hence, it shapes contemporary learners who are particularly conscious about the purpose of them learning a language. Hutchinson and Waters (1992) believe that a learner predominantly understand their need to learn the language and it is the cognizance of a need that ESP ascertains. As learners' needs are at the centre of this process, analysis of the specific learners is the significant point in creating an ESP course. Gomez $(2015$, p.2) stated that "ESP is designed to meet specific needs of learners". Smoak (2003), "ESP is English instruction based on actual and immediate needs of learners. ESP is needs based and task oriented" (p. 27). ESP courses serve a "utilitarian purposes" (Mackay \& Mountford, 1978). Although some scholars have different views on the description of needs analysis; several of them recognise needs analysis as an approach echoing the requirements, desires and needs of learners in their subject area respectively (Fadel \& Elyas, 2015). 
An effective ESP course for working adults contains job-related English lessons. The increased status of English in the ASEAN as well as within major societal dimension such as in economics, social, and politics means that English language proficiency as a key aspect in Myanmar's continued development. It has become a common awareness among all in Myanmar that a good grasp in the English language helps Myanmar citizens' to partake in the world economic system. The Myanmar government is aware of the status of English as an international language and are capitalizing on that trend.

Existing materials have to be complemented with added appropriate topics and language functions applicable to the local government officials in Myanmar. Not only do government officials have to learn how to express these important language topics and functions, they also need lessons on how to use the correct language style, to use it in the right contexts, distinguish levels of formality as it relates to gender, social status, and setting (Schachter, 2013). It is noteworthy that English Language education has taken a new phase where it is recognized as an essential tool for continued growth and expansion within all dimensions of Myanmar (Tan, 2013; UNESCO, 2010). Erling (2014) pointed out that the English language skills are extensively remunerated in corporate world as competency in this language has a constructive impact on economic growth. Hence, as noted by Myanmar stakeholders, mastering the English language fits directly into the urgency to restructure capacity for political, administrative and legal entities, as well as for enhanced delivery of public services.

Government officials are considered to be the link between the public and policy makers. To operate effectively, public administrators should consider the public's desires and concerns. Good communication skills can help public administrators engage with members of the public in debates and discussions, and the issues raised during these exchanges can then be discussed with policy makers (Schachter, 2013). A good grasp of the English language will enable government officials to take part in meetings, discussions and debates confidently (National Educational Strategic Plan 2016-21, 2016). In order to help create a professional representation of the organization, party or country, government officials need to be more confident when using English, especially in a diplomatic setting while resolving conflicts.

\section{Importance of ESP}

Aylazyan and Obdalova (2014) conducted a study on university staff, including professors, teachers, assistants and other adult learners of a very wide range of professions, age and language competence characteristics in Russia. The participants had challenges in expressing their ideas due to the boundaries of vocabulary and grammar. After undergoing and mastering the first module of the English for Business Professional course, the participants mastered the lexis and grammar. They managed to construct logical cohesion in a sentence and the organizational structure of the business professional discourse. The participants' language skills acquisition was accomplished through the integration of specific skills motivated by different needs and interests. Hence, ESP expanded participants' linguistic knowledge.

Algofaili (2019) pointed out that in Saudi, the officers who graduated from the King Abdulaziz Military Academy were incompetent and they struggled in communicating with others in English. This encouraged them to take English courses after they graduate. They realized that teachers do not have well-planned ESP training courses and they may not be familiar with 
teaching English and lack knowledge in this field. The results indicated that English language courses are also highly recommended for effective progress in mastering the language.

\section{Statement of Problem}

A weak grasp in the English language skills curtails effectual communication, causes misinterpretation at times and also creates impediment among the employees (Miina, 2014). English language is used commonly and competence in the language has become a crucial skill in securing an employment in the corporate world. Proficiency in the language means not merely the ability to make grammatically correct sentences but also to equip oneself with workplace related skills like presentation skills, convincing and negotiation skills and interpersonal skills using the right choice of words in English (Clement \& Murugavel, 2018). They also pointed out that the necessitate of being proficient in the English language likely to Due to the global market, the requirements of English language is likely to go on an upward trend and those who are not competent in English language skills may face challenges to climb the ladder professionally. Clement and Murugavel (2018) conducted a research among working adults and revealed that participants indeed highlighted the need for in-house English training to perform their duties efficiently at work.

Hashmi, Rajab, and Sindi (2020) indicated that learners' had a very positive attitude towards learning of the English language and they were aware of their contextual constraints; therefore, it is significant to consider their 'wants' while designing an English language course for dental students. They also illustrated that the English language teachers should use English interactive activities in ESP classes. Purwanto (2014) revealed in his research that faculty officers and retired officers strongly agreed that the mastery of the English language would unite members of ASEAN countries as this would enhance their communication with one another. Purwanto also added that in higher learning institutions teaching of the English language skills must be handled seriously to prepare them to communicate effectively with other countries especially for business dealing. Writing skills are a lesser priority for most employees, but these skills are still important; therefore, the exercises in textbooks can be adapted as necessary for practice in writing. Writing capability standard is that government officials interact with other country leaders who are skilled in writing either initiating want responding to written text accurately.

As a result, improving English language proficiency among government officials in Myanmar is a pressing need. In Myanmar, within the limits of the researcher's knowledge, very little research has been implemented to determine the government officials' needs of English communication skills in executing their official duties effectively in the workplace, and what problems they face when they need to communicate with people or officials from foreign countries in real life situations. Therefore, this study aims to investigate the English language communication needs of Government officials in Myanmar to further understand the situation.

\section{Research Questions}

To what extent did ESP modules for government officials in Myanmar enhance government officials' English language skills?

Are there any significant mean differences in the achievement in English language based on 
working experience?

Are there any significant mean differences in the achievement in English Language based on age?

\section{Methodology}

A mixed method case study approach was used in this study. A total of 50 respondents from the Ministry of Investment and Foreign Economic Relations, government organization participated in this study. This study consisted of three phases: Phase 1, the researcher carried out needs analysis to determine the English language skills needed to execute their duties and responsibilities effectively. The results indicated that the government officials from the Ministry of Investment and Foreign Economic Relations in Myanmar need speaking and writing skills. Based on this information, the researcher prepared a module for speaking and writing. To test the efficacy of the module, the researcher conducted a pre-test before trying out the module. However, this study focuses only on the efficacy of the modules.

In Phase 2, the researchers conducted a pre-test among all 50 respondents from the Ministry of Investment and Foreign Economic Relations before the respondents attended a two-day workshop conducted by the researcher. After the two-day workshop, all the 50 respondents were given a post-test.

Phase 3 includes semi-structured interviews with 10 respondents selected at random.

\section{Research Instruments}

The main instruments used in this study consisted of a test-paper (speaking and writing) and a semi-structured focus group interview question checklist (appendix A) adapted from Arumugam and Kaur (2011). The semi-structured interviews were audiotaped and transcribed verbatimly for analysis.

\section{Focus Group Interviews}

To further evaluate the impact of the modules, participants were also required to selfevaluate their performance by comparing pre-course and post-course differences. Ten respondents were randomly chosen to participate in semi-structured focus group interviews to validate the pre- and post-test results. The interviews were conducted to gather information about the respondents' personal views and perceptions of the ESP modules used in the workshop after the post-test. The interviews were conducted by a non-participant observer which lasted between 15-20 minutes. In this study the semi-structured interview responses were viewed as retrospective reflections. The recorded responses were transcribed using an open coding system and analysed verbatimly. All the respondents gave permission for their responses to be quoted. All excerpts and quotes are assigned pseudonyms R1 - R10.

\section{Non-participant Observer}

There were two non-participant observers for the workshops who were English language instructors from a public institution. The non-participant observers were briefed by the researcher regarding the research process. The researcher also conducted half-day training for all the raters and non-participant observers about their roles and the workshop. 


\section{The Raters}

There were three independent English Language instructors who rated the pre and post-test scripts. All of them had vast experience in the teaching of English as a second language. They volunteered to co-assess the pre and the post-test scripts and speaking task through a series of moderation training sessions. The researcher had a moderation session to have a uniformity in assessing the pre- and post-test scripts. All their evaluation grades were checked if there was any disparity in assessment.

\section{Data analysis}

The data gathered from pre- and post-tests were analysed using a series of paired t-tests to examine if there were improvements after the government officials used the ESP module in their workshop. A series of one way ANCOVA were also used to analyse if age and experience influenced the achievement in the English language skills under investigation which were Speaking and Writing skills. The significant level was set at 0.05 .

\section{Results and Discussions}

The results will be presented according to the research questions of this paper.

RQ1: To what extent did the strategic training for government officials in Myanmar enhance government officials' English language skills?

The results of pre-tests and post-tests of the high ranked government officials are presented in Table 1, Table 2 and Table 3 below.

Table 1: The mean scores of the Pre-tests and Post-tests for Speaking and Writing Skills

\begin{tabular}{|l|l|l|r|r|r|}
\hline \multicolumn{7}{|c|}{ Paired Samples Statistics } \\
\hline & Mean & N & Std. Deviation & $\begin{array}{c}\text { Std. Error } \\
\text { Mean }\end{array}$ \\
\hline Pair 1 & Pre-test Speaking1 & 26.0800 & 25 & 11.63300 & 2.32660 \\
\cline { 2 - 7 } & Post-test Speaking1 & 33.4000 & 25 & 10.53961 & 2.10792 \\
\hline Pair 2 & Pre-test Writing1 & 19.0800 & 25 & 5.33791 & 1.06758 \\
\cline { 2 - 7 } & Post-test Writing1 & 26.3600 & 25 & 5.35319 & 1.07064 \\
\hline
\end{tabular}

The mean scores show that the high ranked government officials fared better in the Speaking $(M=33.4, S D=10.53)$ and Writing $(M=26.36, S D=5.35)$ post-tests compared to the pre-test Speaking $(M=26.08, S D=11.63)$ and Writing $(M=19.08, S D=5.33)$ scores. The results suggest that the officials' speaking and writing performances improved because of the ESP modules used in the workshop.

Table 2: The Correlations between Pre-Tests and Post-Tests for Speaking and Writing Skills

\begin{tabular}{|l|l|r|r|r|}
\hline \multicolumn{5}{|c|}{ Paired Samples Correlations } \\
\hline \multicolumn{2}{|c|}{} & $\mathrm{N}$ & Correlation & \multicolumn{1}{c|}{ Sig. } \\
\hline Pair 1 & $\begin{array}{l}\text { Pre-test Speaking1 Post- } \\
\text { test Speaking1 }\end{array}$ & 25 & .949 & .000 \\
\hline Pair 2 & $\begin{array}{l}\text { Pre-test Writing1 Post- } \\
\text { test Writing1 }\end{array}$ & 25 & .678 & .000 \\
\hline
\end{tabular}


Looking at the correlations between the pre- and post-tests, it was found that there was a strong positive significant correlation in the Speaking skills $(r=.949, p<0.01)$ and a moderate positive significant correlation in the Writing skills $(r=.678, p<0.01$. The results indicate that those who got higher scores in the Speaking and Writing pre-tests, would also get higher scores in the Speaking and Writing post-tests. This could be attributed to the use of the ESP modules that helped to enhance the participants understanding and learning of the skills.

Table 3: The Paired Samples Tests for Pre-Tests and Post Tests for Speaking and Writing

\begin{tabular}{|c|c|c|c|c|c|c|c|c|}
\hline \multicolumn{9}{|c|}{ Paired Samples Test } \\
\hline & \multicolumn{5}{|c|}{ Paired Differences } & \multirow[b]{3}{*}{$\mathrm{t}$} & \multirow[b]{3}{*}{ df } & \multirow{3}{*}{$\begin{array}{l}\text { Sig. (2- } \\
\text { tailed) }\end{array}$} \\
\hline & \multirow[b]{2}{*}{ Mean } & \multirow{2}{*}{$\begin{array}{c}\text { Std. } \\
\text { Deviatio } \\
n\end{array}$} & \multirow{2}{*}{$\begin{array}{l}\text { Std. } \\
\text { Error } \\
\text { Mean }\end{array}$} & \multicolumn{2}{|c|}{$\begin{array}{c}95 \% \text { Confidence } \\
\text { Interval of the } \\
\text { Difference }\end{array}$} & & & \\
\hline & & & & Lower & Upper & & & \\
\hline \begin{tabular}{|l|l} 
Pair 1 & Pre-test \\
& Speaking1 - \\
& Post-test \\
& Speaking1
\end{tabular} & 7.32000 & 3.71618 & .74324 & 8.85396 & 5.78604 & -9.849 & 24 & .000 \\
\hline \begin{tabular}{|l|l|} 
Pair 2 & Pre-test \\
& Writing1 - \\
& Post-test \\
& Writing1
\end{tabular} & 7.28000 & 4.28680 & .85736 & 9.04950 & 5.51050 & -8.491 & 24 & .000 \\
\hline
\end{tabular}

The paired sample test shows there was a significant mean difference between Speaking pretest and Speaking post-test results $(M=7.32, S D=3.71), t(24)=-9.849, p<0.01$. There was also a significant mean difference between the Writing pre-test and Writing post-test $(M=7.28$, $\mathrm{SD}=4.28), \mathrm{t}(24)=-8.491, \mathrm{p}<0.01$ results. This indicates that there was an improvement in the Speaking and Writing scores after they used the ESP module.

The results in Table 4, Table 5 and Table 6 below are based on the performance of the low ranked officials.

Table 4: The mean scores of the Pre-tests and Post-tests for Speaking and Writing Skills

\begin{tabular}{|l|l|l|r|r|r|}
\hline \multicolumn{7}{|c|}{ Paired Samples Statistics } \\
\hline & Mean & N & Std. Deviation & $\begin{array}{c}\text { Std. Error } \\
\text { Mean }\end{array}$ \\
\hline Pair 1 & Pre-test Speaking2 & 35.7600 & 25 & 11.27416 & 2.25483 \\
\cline { 2 - 6 } & Post-test Speaking2 & 40.2400 & 25 & 9.79064 & 1.95813 \\
\hline Pair 2 & Pre-test Writing2 & 16.3200 & 25 & 5.24182 & 1.04836 \\
\cline { 2 - 6 } & Post-test Writing2 & 25.8800 & 25 & 6.75968 & 1.35194 \\
\hline
\end{tabular}

The mean scores show that the low ranked government officials fared better in the Speaking $(M=40.24, S D=9.79)$ and Writing $(M=25.88, S D=6.75)$ post-tests compared to the Speaking $(M=35.76, S D=11.27)$ and Writing $(M=16.32, S D=5.24)$ pre-tests. 
Table 5: The Correlations between Pre-Tests and Post-Tests for Speaking and Writing Skills

\begin{tabular}{|c|c|c|c|c|}
\hline \multicolumn{5}{|c|}{ Paired Samples Correlations } \\
\hline & & $\mathrm{N}$ & Correlation & Sig. \\
\hline Pair 1 & $\begin{array}{l}\text { Pre-test Speaking2 Post- } \\
\text { test Speaking2 }\end{array}$ & 25 & .837 & .000 \\
\hline Pair 2 & $\begin{array}{l}\text { Pre-test Writing2 \& Post- } \\
\text { test Writing2 }\end{array}$ & 25 & .718 & .000 \\
\hline
\end{tabular}

Looking at the correlations between the pre- and post-tests, it was found that there was a strong positive significant correlation in both the Speaking $(r=.837, p<0.01)$ and Writing skills $(r=.718, p<0.01)$. The results indicate that those who got high scores in the Speaking and Writing pre-tests achieved higher scores in the Speaking and Writing post-tests.

Table 6: The Paired Samples Tests for Pre-Tests and Post-Tests for Speaking and Writing Table 6 shows the paired samples test indicates a significant mean difference between

\begin{tabular}{|c|c|c|c|c|c|c|c|c|c|}
\hline \multicolumn{10}{|c|}{ Paired Samples Test } \\
\hline & & \multicolumn{5}{|c|}{ Paired Differences } & \multirow[b]{3}{*}{$\mathrm{t}$} & \multirow[b]{3}{*}{$\mathrm{df}$} & \multirow{3}{*}{$\begin{array}{l}\text { Sig. (2- } \\
\text { tailed) }\end{array}$} \\
\hline & & \multirow{2}{*}{ Mean } & \multirow{2}{*}{$\begin{array}{c}\text { Std. } \\
\text { Deviation }\end{array}$} & \multirow{2}{*}{$\begin{array}{c}\text { Std. Error } \\
\text { Mean }\end{array}$} & \multicolumn{2}{|c|}{\begin{tabular}{|c|} 
95\% Confidence \\
Interval of the \\
Difference
\end{tabular}} & & & \\
\hline & & & & & Lower & Upper & & & \\
\hline $\begin{array}{l}\text { Pair } \\
1\end{array}$ & $\begin{array}{l}\text { Pre-test Speaking2 } \\
\text { - Post-test } \\
\text { Speaking2 }\end{array}$ & -4.48000 & 6.17198 & 1.23440 & -7.02767 & 1.93233 & -3.629 & 24 & .001 \\
\hline $\begin{array}{l}\text { Pair } \\
2\end{array}$ & $\begin{array}{l}\text { Pre-test Writing2 - } \\
\text { Post-test Writing2 }\end{array}$ & -9.56000 & 4.71770 & .94354 & 11.5073 & 7.61263 & -10.132 & 24 & .000 \\
\hline
\end{tabular}

Speaking pre-test and Speaking post-test $(M=4.48, S D=6.17), t(24)=-3.629, p<0.01$. There is also a significant mean difference between Writing pre-test and Writing post-test $(M=9.56$, $\mathrm{SD}=4.71), \mathrm{t}(24)=-10.132, \mathrm{p}<0.01$. This suggests that the workshop participants improved a lot in their speaking and writing skills after they underwent the training that used the ESP module.

Tables 7, 8 and 9 show the performance of both the high ranked and the low ranked government officials.

Table 7: The mean scores of the Pre-tests and Post-tests for Speaking and Writing Skills

\begin{tabular}{|l|l|l|r|r|r|}
\hline \multicolumn{7}{|c|}{ Paired Samples Statistics } \\
\hline & Mean & N & Std. Deviation & $\begin{array}{c}\text { Std. Error } \\
\text { Mean }\end{array}$ \\
\hline Pair 1 & Pre-test Speaking & 30.9200 & 50 & 12.34676 & 1.74610 \\
\cline { 2 - 7 } & Post-test Speaking & 36.8200 & 50 & 10.64394 & 1.50528 \\
\hline \multirow{2}{*}{ Pair 2} & Pre-test Writing & 17.7000 & 50 & 5.41822 & .76625 \\
\cline { 2 - 7 } & Post-test Writing & 26.1200 & 50 & 6.03946 & .85411 \\
\hline
\end{tabular}

Looking at the overall performance of both groups, the results show that the government officials fared better in the Speaking $(M=36.82, S D=10.64)$ and Writing $(M=26.12, S D=6.03)$ post-tests compared to the Speaking $(M=30.92, S D=12.34)$ and Writing $(M=17.70, S D=5.41)$ pre-test scores. 
Table 8: The Correlations between Pre-Tests and Post-Tests for Speaking and Writing Skills

\begin{tabular}{|l|r|r|r|r|}
\hline \multicolumn{5}{|c|}{ Paired Samples Correlations } \\
\hline \multicolumn{2}{|l|}{} & $\mathrm{N}$ & Correlation & \multicolumn{1}{c|}{ Sig. } \\
\hline Pair 1 & $\begin{array}{l}\text { Pre-test Speaking \& } \\
\text { Post-test Speaking }\end{array}$ & 50 & .906 & .000 \\
\hline Pair 2 & $\begin{array}{l}\text { Pre-test Writing \& Post- } \\
\text { test Writing }\end{array}$ & 50 & .682 & .000 \\
\hline
\end{tabular}

The correlations between the pre- and post-tests for both groups also show that there was a strong positive significant correlation in the Speaking skills $(r=.906, p<0.01)$ and there was a moderate positive significant correlation in the Writing skills $(r=.682, p<0.01)$. In conclusion, for both groups, those who obtained high scores in the Speaking and Writing pre-tests scored higher in the Speaking, Writing and Total post-tests.

Table 9: The Paired Samples Tests for Pre-Tests and Post-Tests for Speaking and Writing

\begin{tabular}{|c|c|c|c|c|c|c|c|c|}
\hline \multicolumn{9}{|c|}{ Paired Samples Test } \\
\hline & \multicolumn{5}{|c|}{ Paired Differences } & \multirow[b]{3}{*}{$\mathrm{t}$} & \multirow[b]{3}{*}{$\mathrm{df}$} & \multirow{3}{*}{$\begin{array}{l}\text { Sig. (2- } \\
\text { tailed) }\end{array}$} \\
\hline & \multirow[b]{2}{*}{ Mean } & \multirow{2}{*}{$\begin{array}{c}\text { Std. } \\
\text { Deviatio } \\
n\end{array}$} & \multirow{2}{*}{$\begin{array}{l}\text { Std. } \\
\text { Error } \\
\text { Mean }\end{array}$} & \multicolumn{2}{|c|}{$\begin{array}{l}\text { 95\% Confidence } \\
\text { Interval of the } \\
\text { Difference }\end{array}$} & & & \\
\hline & & & & Lower & Upper & & & \\
\hline \begin{tabular}{|l|l} 
Pair 1 & $\begin{array}{l}\text { Pre-test Speaking- } \\
\text { Post-test Speaking }\end{array}$
\end{tabular} & -5.90000 & 5.24210 & .74134 & -7.38979 & 4.41021 & -7.959 & 49 & .000 \\
\hline \begin{tabular}{l|l} 
Pair 2 & Pre-test Writing- \\
& Post-test Writing
\end{tabular} & -8.42000 & 4.60740 & .65159 & -9.72941 & $\begin{array}{r}7 \\
7.11059\end{array}$ & -12.922 & 49 & .000 \\
\hline
\end{tabular}

The paired sample tests show that there was a significant mean difference between Speaking pre-test and Speaking post-test $(M=5.90, S D=5.24), t(24)=-7.959, p<0.01$. There was also a significant mean difference between Writing pre-test and Writing post-test $(M=8.42$, $\mathrm{SD}=4.60), \mathrm{t}(24)=-12.922, \mathrm{p}<0.01$. This indicates that there was an improvement of the Speaking and Writing scores of government officials from both groups after they used the training modules.

Interviews with both the low and high ranked officials were carried out at the end of the workshop to understand the impact of the ESP modules on their speaking performance. Analysis of the comments and responses after the Speaking post-test revealed that for high rank officials, they reported the ESP modules encouraged them to speak and discuss in English. The speaking module requires workshop participants to complete daily workplace tasks like carrying out small talk, telephone conversation, performing oral presentation and conducting meeting in English. As R-5 stated, 'Now I understand how to conduct effective presentation and meeting'. R-3 further elaborated that the key expressions in English telephone conversations at workplace covered in the speaking module were very useful. The language focus on common language expressions made him/her be more confident to conduct telephone conversation in English with foreigners at work. R-2 on one hand noted, 'Before I used to translate everything from Myanmar to English, but now I can talk directly in English.' Thus, the interviews with the high rank officials indicate that the ESP speaking module succeeded in developing greater tendency for them to employ English in their professional spoken discourses. On the other hand, the low rank officials' responses offered 
further insights into the effectiveness of the ESP speaking module in improving their English grammar, vocabulary and pronunciation. As pointed out by R-9 and R-10, they could resolve issues via telephone in English with more confidence after their training as they learned how to speak in complete sentences without grammatical errors and correct pronunciation. R-6 and R-7 also noted that they could present in seminar, handle meeting and participate in a forum and workshop with more confidence after their training. Thus, it can be concluded that the ESP speaking also accounts for positive effects on the low rank officials' self-confidence and workplace spoken skills. All in all, the speaking module covers both the high and low rank officials spoken workplace needs as confirmed by R-1, '...topics [in] the modules are very suitable for speaking in English language effectively at the workplace'.

Additionally, the interviews reveal that both high and low rank officials were required to write e-mail, memo, letter, executive summary of project and report. Their problems in composing these professional genres include grammar, spelling, vocabulary and format. After the workshop however, R-1, R-3 and R-8, reported they were pleased to be able to write email, memo, executive summary and report in a more organized manner. As highlighted by R-2, 'The writing modules help me to prepare better reports, letters, memos [and] business proposals in the English language ...[as well as] helped me to write well with effective methods.' This was mostly likely the result of his/her exposure to the typical format or structure of the written genres. Some of the participants (R-3, R-7 and R-8) also highlighted they were able to generate more ideas to be included in the report. Overall, the writing modules helped to improve their writing abilities.

\section{Research question 2}

Are there any significant mean differences in the achievement in English language based on work experience?

A one-way ANCOVA test was conducted to investigate whether work experience influenced the achievement of English Speaking and Writing skills whilst controlling for the pre-test. The Levene's test as shown in Table 10 reveals that the $p$-value was not significant $(p>0.05)$, thus, this indicates that the data were normally distributed and the assumptions were met.

Table 10: The Levene's Test of Equality of Error Variances

\begin{tabular}{|c|c|c|c|}
\hline \multicolumn{4}{|c|}{ Levene's Test of Equality of Error Variances $^{\text {a }}$} \\
\hline Dependent Variable: & Post-Test \\
\hline F & df1 & df2 & Sig. \\
\hline 1.111 & 354 \\
\hline
\end{tabular}


Table 11: Tests of Between Subjects Effects

\begin{tabular}{|c|c|c|c|c|c|c|}
\hline \multicolumn{7}{|c|}{$\begin{array}{ll}\text { Tests of Between-Subjects Effects } \\
\end{array}$} \\
\hline \multicolumn{7}{|c|}{ Dependent Variable: Post-Test } \\
\hline Source & $\begin{array}{l}\text { Type III Sum of } \\
\text { Squares }\end{array}$ & $\mathrm{df}$ & Mean Square & $\mathrm{F}$ & Sig. & $\begin{array}{c}\text { Partial Eta } \\
\text { Squared }\end{array}$ \\
\hline Corrected Model & $8601.615^{a}$ & 4 & 2150.404 & 75.529 & .000 & .870 \\
\hline Intercept & 1964.052 & 1 & 1964.052 & 68.984 & .000 & .605 \\
\hline Pre-test & 7062.866 & 1 & 7062.866 & 248.070 & .000 & .846 \\
\hline Work Experience & 105.139 & 3 & 35.046 & 1.231 & .310 & .076 \\
\hline Error & 1281.205 & 45 & 28.471 & & & \\
\hline Total & 207955.000 & 50 & & & & \\
\hline Corrected Total & 9882.820 & 49 & & & & \\
\hline
\end{tabular}

Table 10 shows that there was no significant mean difference in the post-test $F(3,45)=1.231$, $p>0.05$, between the work experience, while adjusting for the pre-test. The partial ETA Squared value indicates that the effect size for work experience was small (0.076). It shows that only $7.6 \%$ of the variance in the post-test was explained by the work experience. These statistical findings show no mediating effect from work experience on the participants' speaking and writing achievements. This echoes findings from other studies that found tailormade ESP module content that cater the learners' specific needs using authentic scenarios and tasks performed at workplace helped enhance their awareness of the range of structural and linguistic choices available in the professional settings in which they are actually made (Lejot, 2017; Zainuddin, Pillai, Dumanig \& Phillip, (2019).

RQ3. Are there any significant mean differences in the achievement in English Language based on age?

A one-way ANCOVA test was conducted to investigate whether age had any effects on the achievement in English language whilst controlling for the pre-test. The Levene's test showed that the $p$-value was not significant ( $p>0.05)$, thus, this indicated that the data were normally distributed and the assumptions were met.

\begin{tabular}{|c|c|c|c|}
\hline \multicolumn{4}{|c|}{ Levene's Test of Equality of Error Variances ${ }^{a}$} \\
\hline \multicolumn{4}{|c|}{ Dependent Variable: PostTest } \\
\hline $\mathrm{F}$ & df1 & $\mathrm{df} 2$ & Sig. \\
\hline .536 & 3 & 46 & .660 \\
\hline
\end{tabular}


INTERNATIONAL JOURNAL OF ACADEMIC RESEARCH IN BUSINESS AND SOCIAL SCIENCES Vol. 11, No. 3, 2021, E-ISSN: 2222-6990 @ 2021 HRMARS

\begin{tabular}{|c|c|c|c|c|c|c|}
\hline \multicolumn{7}{|c|}{ Tests of Between-Subjects Effects } \\
\hline \multicolumn{7}{|c|}{ Dependent Variable: Post-Test } \\
\hline Source & $\begin{array}{c}\text { Type III Sum of } \\
\text { Squares }\end{array}$ & df & Mean Square & $\mathrm{F}$ & Sig. & $\begin{array}{l}\text { Partial Eta } \\
\text { Squared }\end{array}$ \\
\hline Corrected Model & $8528.594^{a}$ & 4 & 2132.149 & 70.850 & .000 & .863 \\
\hline Intercept & 1751.143 & 1 & 1751.143 & 58.189 & .000 & .564 \\
\hline Pre-test & 7623.967 & 1 & 7623.967 & 253.339 & .000 & .849 \\
\hline Age & 32.119 & 3 & 10.706 & .356 & .785 & .023 \\
\hline Error & 1354.226 & 45 & 30.094 & & & \\
\hline Total & 207955.000 & 50 & & & & \\
\hline Corrected Total & 9882.820 & 49 & & & & \\
\hline
\end{tabular}

The tests of between-subjects effects table showed that there was no significant mean difference in the post-test $F(3,45)=0.356, p>0.05$, between the age groups, while adjusting for the pre-test. The partial ETA Squared value indicated that the effect size for age was small (0.023). It shows that only $2.3 \%$ of the variance in the post test was explained by the age group. As can be seen in the table above, no significant correlations were found between age and the performance.

In addition, the quantitative results were later corroborated by the analysis of the participants' interviews that show age did not show significant correlation in the participants' oral and written achievements. Some of the participants reported hours of productive use of English language to complete oral and written tasks in the modules had positive association to their higher fluency, accuracy and lexical diversity. Thus, it may be argued that the older participants did not have cognitive maturation advantage over the younger participants.

Semi-structured Interview Interpretations of Module Effectiveness

Interviews with the participants were carried out at the end of the workshop to understand the impact of the ESP module on workshop participants' performance. Analysis of their comments and responses after the post-test revealed that R-3 reported the workshop encouraged the participant to use English to speak and discuss in English which helped improve his/her proficiency in the language. This indicates that the use of the ESP speaking module in the workshop succeeded in developing greater tendency for the participants to employ English in their conversations and discussions. R-3 further confirmed that the key expressions in English telephone conversations at workplace covered in the module were very useful. R-3 elaborated that he/she was more confident to conduct telephone conversation in English with foreigners at work. R-3 noted, 'Before I used to translate everything from Myanmar to English but, now I can talk directly in English.'

Additionally, the interviews reveal that R-8 was pleased to be able to write email, memo, executive summary and report in a more organized manner after the workshop. This was mostly likely the result of exposure to structural workplace written genres covered in the ESP writing module. The participant also highlighted he/she was able to generate more ideas to be included in the writing of workplace genres.

Some participants' responses offered further insights into the effectiveness of the ESP speaking module in improving their English grammar, vocabulary and pronunciation. As 
pointed out by R-3, R-9 and R-10, they believed that they can resolve issues via telephone in English with more confidence after their training. R-5, R-6 and R-7 also noted that they could present in seminar, handle meeting and participate in a forum and workshop better after their training. As R-3 stated, 'I understand how to conduct effective presentation and meeting'. Thus, it can be concluded that the qualitative data also account for positive effects of the ESP training module on the workshop participants' self-confidence, and workplace spoken and written skills.

\section{Conclusion}

In short, the ESP writing modules assisted to improve the respondents' speaking and writing skills in the English language as both the high and low rank officials showed an improvement in their posttest compared to their pretest grades. Besides, they also indicated that the modules were approapriate for them to perform effectively at the workplace. The qualitative results too showed that the ESP training brought a positive impact like enhancing the officials' self-confidence. However, it was clear that age and work experience of the respondents did not show significant correlation in the participants' oral and written achievements.

In conclusion, the present study quantitative and qualitative findings revealed positive effects of the tailor-made modules that are parallel to the workshop participants' day-to-day work workplace needs. Both the high and low rank officials had significant improvements in their Speaking and Writing outputs after they used the ESP modules. Findings of the study also showed age and work experience did not influence their achievements which means the customized module materials are suitable to be used for participants regardless of age and work experience.

\section{Recommendations for Future Study}

Firstly, this study is solely based on one ministry, the Ministry of Investment and Foreign Economic Relations where the researcher applied a triangulation method of semi-structured interviews with the Director, Heads of Department, senior and junior officials at the Ministry of Investment and Foreign Economic Relations. These officials require English language skills as they are assigned to communicate and correspond with international counterparts. It could be further improved by interviewing officials from other ministry and departments to elicit their opinions and needs in developing an ESP syllabus for their respective workplace needs. Moreover, in the future, researchers could conduct a "needs analysis" with the other officials from other ministries in Myanmar hence, a larger data set could be gathered to deduce more extensive findings.

Needs Analysis results of this study were based on the past officials' perspectives using classroom-learning analyses strategy suggested by Brown (2016) which may not fully represent needs of other stakeholders such as ESP developers and curriculum developers. Therefore, future research should collect information data from those stakeholders to determine needs from different perspectives.

In summing up, it is recommended that future research should collect more quantitative data from structured questionnaire as well as more qualitative data by conducting more interviews with different groups stakeholders to gain more in depth data which might better compliment data from questionnaires. Learning training courses based on communication 
skills is needed for officials of Myanmar. Effective contents both using English official language in the organization and can encourage the employees to improve the communication skills in the workplace. It is necessary to consider that effective English courses and effective contents can be beneficial for employees.

\section{Implications of Study}

The study focuses on the effectiveness of ESP module in enhancing the speaking and writing skills of the Myanmar government officials. Since the findings revealed that the ESP module helped improve these officials' speaking and writing abilities, it is important for the Myanmar government to understand that some intervention programmes using proper ESP modules could be conducted for their officials. Investment in such programmes would not only be practical, but also benefit the Myanmar government in term of work efficiency. In addition, it also gives an insight on how the ESP modules on these productive skills could be designed to cater the needs of the government officials in executing their daily tasks. The modules can be developed based on their language proficiency levels and authentic workplace materials so that the officials can be exposed to authentic language use and "hands-on" practice. It is hoped that the officials will be able to confidently use the skills that they acquire through these programmes in their workplace.

\section{Reference}

Algofaili, S. R. (2019). A Study of Saudi Teachers' and Students' Attitudes toward the Use of ESP at a Saudi Military Academy. ProQuest LLC, Ph.D. Dissertation, The University of Memphis, ERIC Number: ED602167.

Arumugam, N., \& Kaur, N. (2011). Needs Analysis on the Importance of English Communication Skills for Medical Assistants, Journal of Institutional Research South East Asia. JIRSEA: Vol. 9, no. 1, May/June 2011- ISSN 1675-6061

Arumugam, N., Muchar, J., Bala Subramaniam, A. L., \& Selvanayagam. (2020). Figure It Out: Creative Language Expressions in ESL Writing Classroom. Universal Journal of educational Research, 9 (8), 4187 -4192. ISSN: 2332-3213 (Online).

URL: http://www.hrpub.org/journals/jour_archive.php?id=95.

Aylazyana, Y. P., \& Obdalovab, O. A. (2014). ESP Adult Course Implications for Professional Competence Development. Procedia - Social and Behavioral Sciences, 381 - 385 Available online at www.sciencedirect.com ScienceDirect 1877-0428 @

Cho Mar, M. T. (2020). Myanmar Youth and Impact of English Language Proficiency Towards Job Grabbing. Advances in Social Science, Education and Humanities Research, 477, Proceedings of the International Conference on Community Development (ICCD 2020), Ho Chi Minh, Vietnam.

Chao, R. Y. (2018) Higher Education Systems and Institutions, Myanmar. In: Teixeira P., Shin J. (eds) Encyclopedia of International Higher Education Systems and Institutions. Springer, Dordrecht. https://doi.org/10.1007/978-94-017-9553-1_511-1

Clement, A., \& Murugavel, T. (2018). English for the workplace: The importance of English language skills for effective performance. The English Classroom, 20(1), 1-15.

Department of Higher Education (Lower Myanmar) of Ministry of Education. (2012). Higher Education in Myanmar Structure, Long -Term Plans Evaluation of Current Situation \& Future Plans, Higher Education Policy and Accessibility to Quality Education. Available from http://www.myanmarFeducation.edu.mm 
Department of Higher Education (Lower Myanmar) of Ministry of Education. (2012b). Panorama of Myanmar Higher Education". http://www.myanmarFeducation.edu.mm Economic and Social Reforms- Policy Priorities for 2012-2015 towards the Long-Term

Elyas, T., \& Alghofaili, N. (2019). Native English speakers versus non-native English speakers: The impact of language teachers on EFL learner's English proficiency. English Review Journal of English Education 7(2), DOI: 10.25134/erjee.v7i2.1773

Fadel, S., \& Elyas, T. (2015). ESP Needs Analysis to Integrate a Scientific Reading Program in the English Language Institute at King Abdul Aziz University. International Journal of Educational Investigations 2(4), 14-27.

Erling, E. (2017). Language planning, English language education and development aid in Bangladesh. Current Issues in Language Planning 18(1):1-19. DOI:10.1080/14664208.2017.1331496

Erling, J. (2014). The Role of English in Skills Development in South Asia: Policies, Interventions and Existing Evidence. [ebook] British Council. Available at: https://www.britishcouncil.Ik/sites/default/files/role_of_english_in_skills_developme nt_in_south_asia_inside.pdf [Accessed 15 Jul. 2017].

Gjata, F. (2017). English and its Role in the Development of Tourism in Albania and in the World, Anglisticum Journal (IJLLIS), 6(11), $56-60$. https://doi.org/10.5281/zenodo.1079902

Gómez, D. R. (2014). Older-adult foreign language learning: instructors' beliefs and some recommendations. In N. Sonda \& A. Krause (Eds.), JALT2013 conference proceedings. Tokyo: JALT.

Gomez, D. R. (2015). Critical Geragogy and Foreign Language Learning: An Exploratory Application. Educational Gerontology, 1-17. DOI: 10.1080/03601277.2015.1083388

Hashmi, U. M., Rajab, H., \& Sindi, A. E. (2020).Dental Students' Perceptions of ESP Material and its Impact on Their Language Proficiency: A Case Study of a Saudi Arabian University. Arab World English Journal, 10(4), 3-17. DOI: https://dx.doi.org/10.24093/awej/vol10no4.1

Hutchinson, T., \& Waters, A. (1987). English for specific purposes: A learningcentered approach. Cambridge: Cambridge University Press.

Hutchinson, T., \& Waters, A., (1992). English for Specific Purposes: A Learning-centered Approach. Cambridge: Cambridge University Press.

Kirkpatrick, A. (2017). Language education policy among the Association of Southeast Asian Nations (ASEAN). European Journal of Language Policy 9(1):7-25. DOI: $10.3828 /$ ejlp.2017.2

Lejot, E. (2017). Requests for help in a multilingual professional environment. Testimonies and actantial models. Open Linguistics, 3, 516-539. http://doi.org/10.1515/opli-20170026

Malthus, C., Holmes, J., \& Major, G. (2005). Completing the circle: Research-based classroom practice with EAL nursing students. New Zealand Studies in Applied Linguistics, 11 (1), pp. 65-89.

Mackay, R. (1978). Identifying the nature of learners' needs. In R. Mackey and A. Mountford. (eds.). 1978. English for Specific Purposes. London: Longman.

Miina, O. (2014). Effects of using English in business communication in Japanese-based multinational corporations. Master's Thesis. University of Oulu.

MOE. (2013). Education System in Myanmar: Self-Evaluation and Future Plans, 
http://www.myanmar-education.edu.mm/dhel/education-system-inmyanmar/education-law/, Retrieved 17 July 2018.

Myanmar Institute for Integrated Development. (2018). Taking a Holistic, People Centred Approach to Development. Retrieved from https://namati.org/network/organization/myanmar-institute-for-integrated-dev National Educational Strategic Plan 2016-21. (2016). The Government of the Republic of the Union of Myanmar, Ministry of Education, Nay Pyi Taw. Retrieved from https://www.sea-vet.net/resources/204-myanmar-national-education-strateg

Oktarin, R., Syahrial, S., \& Harahap, A. (2019). Needs Analysis of ESP for Tourism Study Program At Smkn 7 (Senior Vocational School) Kota Bengkulu. Journal of English Education and Teaching, 3(1), 14-28. https://doi.org/10.33369/jeet.3.1.14-28

Pandey, M., \& Pandey, P. (2014). Better English for better employment opportunities. International journal of multidisciplinary approach and studies, 1(4), 93-100.

Purwanto, E. (2016). An Anti-Encroachment Strategy for the Tropical Rainforest Heritage of Sumatra: Towards New Paradigms Edi Purwanto. Bogor: Tropenbos International Indonesia.

Robinson, P. C. (1991). ESP Today: Practitioner's Guide. New York: Prentice Hall

Schachter, A. (2013). Sometimes it's not what you say or how you say it... it's the language you pick, Arts, Culture \& Media. Retrieved from https://www.pri.org/stories/2013-0926/sometimes-its-not-what-you-say-or-how-you-say-it-its-language-you-pick

Smoak, R. (2003). What is English for Specific Purposes, English Teaching Forum, 41(2), April 2003.

Soe, T. (2015). A Study of Contemporary Trends and Challenges of English Language Teaching in Myanmar. International Conference on Burma/Myanmar Studies Burma/Myanmar in Transition: Connectivity, Changes and Challenges University Academic Service Centre (UNISERV), Chiang Mai University, Thailand,24F25 July 2015.

Stokke, K., Vakulchuk, R., \& Overland, I. (2018). Myanmar: A Political Economy Analysis Report commissioned by the Norwegian Ministry of Foreign Affairs 2018. Retrieved from https://reliefweb.int/report/myanmar/myanmar-political-economy-analysis

Takahashi, K. (2014). English in Myanmar. Retrieved from Language on the Move website: http://www.languageonthemove.com/category/language-globalization/page/2

Tan, B. T. (2013). Learning English in the periphery: A view from Myanmar (Burma). Journal of Language teaching research, 18 (1), 95-117 https://doi.org/10.1177/1362168813505378

The British Academy. (2015). Language Choice in Higher Education: Challenges and Opportunities. Retrieved from https://www.thebritishacademy.ac.uk/documents/1066/Myanmar_Workshop_R

Ting, S. H., Marzuki, E., Chuah, K. M., Misieng, J., \& Jerome, C. (2017). Employers' views on importance of English proficiency and communication skill for employability in Malaysia. Indonesian Journal of Applied Linguistics, 7(2), 315-327.

UNICEF Myanmar. (2013). Improving Learning Environment for Primary School Children in Myanmar, http://www.unicef.org/myanmar/media_20729.html, Retrieved 15 July 2019.

UNESCO. (2010). UIS Statistics in Brief: Education Profile - Myanmar. Paris: UNESCO Institute of Statistics. 5 Vine, K. (2010). Quantitative Study of Child Friendly School Implementation in Myanmar. UNICEF:Myanmar. 
Wan, R., \& Philip, B. (2012). Developing an English for Specific Purposes (ESP) Module for Oil Palm Supervisors in Sarawak, Malaysia. Paper presented in ESTCON-ICMeSH2012, June 12-14, 2012, KLCC, Kuala Lumpur.

Zainuddin, S. Z. B., Pillai, S., Dumanig, F. P., and Phillip, A. (2019), "English language and graduate employability", Education + Training, Vol. 61 No. 1, pp. 7993. https://doi.org/10.1108/ET-06-2017-0089 